\title{
Factors that Influence Evaluation Skills of Arabic Language Teachers in Saudi Arabia: A Regression Analysis Study
}

\author{
Faisal Alzahrani, Ph.D. \\ Ministry of Education, PO Box: 12435, Riyadh, Saudi Arabia \\ E-mail: faljmhoor@gmail.com \\ Beth Winfrey Shindel, Ph.D. \\ School of Education, Saint Louis University, 3500 Lindell Blvd, Saint Louis MO, United States 63103 \\ E-mail: beth.shindel@slu.edu
}

\begin{abstract}
Evaluation of learning is a process used to maintain and improve the quality of education at all grade levels. Evaluation in any subject is becoming of increasing interest to the educational professionals. Best practice for classroom teachers for all school subjects includes active and continuous involvement in the evaluation process. In Saudi Arabia, teachers of Arabic language faced numerous obstacles, which are mostly attributed to the teachers' lack of alignment of planning, implementation, and evaluation of learning outcomes. The purpose of this study was to investigate factors that influence the evaluation skills of Arabic language teachers at all public and private schools in the Majmaah School District, Saudi Arabia. Using descriptive statistics and multiple regression, three research questions were answered. From the estimated population of 250-280 Arabic teachers, 158 individuals responded to a survey (response rate $=56.4 \%$ to $63.2 \%$ ). Results indicated that all elements in the Evaluation Needs Scale were ranked between less needed and most needed (mean range $=2.61$ to 2.44). Analysis revealed planning and implementation needs as predictors explained $47.10 \%$ of the variance (unique and shared) in evaluation needs, $F(2,157)=70.80, p=.00$. Of these two predictors, planning needs made the larger unique contribution. Implications for the professional development of Arabic teachers are discussed.
\end{abstract}

DOI: $10.7176 / \mathrm{JEP} / 11-23-09$

Publication date:August $31^{\text {st }} 2020$

\section{Introduction}

Evaluation of learning is a process used to maintain and improve the quality of education at all grade levels. In addition, evaluation in any subject is becoming of increasing interest to the educational professionals. The teachers, using strong evaluation skills, help students learn better. Teaching at Risk: A Call to Action suggested successful teachers use strong evaluation processes to understand that supporting "children to learn is an investment in human potential" (Borko, 2004, p. 3). Jabbarifar (2009) listed five basic components of evaluation in education (a) articulating the purpose of the educational system, (b) identifying and collecting relevant information, (c) having ideas that are valuable and useful to learners in their lives and professions, (d) analyzing and interpreting information for learners, and (e) using classroom management or classroom decision making.

Best practice for classroom teachers for all school subjects includes active and continuous involvement in the evaluation process. Classroom teachers pay attention to three components when they evaluate their students (Disha, N.A). First is the purpose of instruction indicated by the learning objectives - the "WHY". Second is the plan that describes the learner experiences to attain the learning objectives - the "HOW. Third is the practices which actually take place in the classroom- the "WHAT" or the learner appraisal. All three components need to be connected in order of the evaluation process occur in the taught subject.

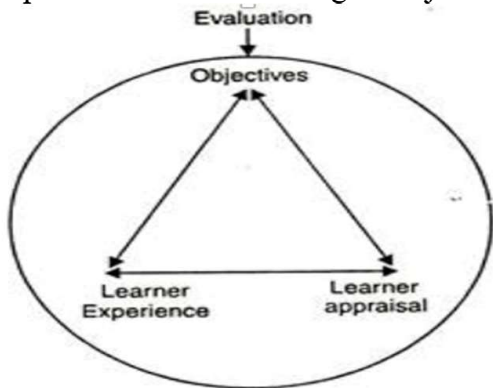

Figure 1. The three evaluation components (Figure created by author from the research of Disha, N.A)

Ministries of education, departments of education, and school districts in any educational system can improve the quality of their educational programs at all levels in all subjects using an evaluation process (Al-Hazmi, 2003; Alnahdi, 2014). Al-Hazmi, (2003) and Alnahdi (2014) added that If teachers increase their evaluation skills and performance, they can serve their country and educate their children better. 
Language arts, a curriculum basic, can be continually reviewed for the quality and relevance for students. To this end, language arts teachers need professional development opportunities that focus on the development of evaluation skills. Few studies have addressed professional development that can improve language arts teachers' skills, knowledge, instructions, and evaluation in the classrooms (Beach, 2011; Newell, Beach, Smith, \& VanDerHeide, 2011). Moreover, language arts teachers mostly participate in other areas of professional development such as technologies, student discipline, and classroom management. These teachers participate to a lesser extent in professional development that focuses on specific language arts skills such as reading instruction or assessment process (Wei, Darling-Hammond, \& Adamson, 2010).

Indeed, Arabic Language Teachers (ALT) in Saudi Arabia need to be investigated to determine their needs and interests in order to improve their teaching skills and performance. Al Ghamdi (2015) addressed different issues regarding teaching and learning Arabic language at public schools in Saudi Arabia. This research indicated teachers who are teaching and students who are learning Arabic language faced numerous obstacles, which are mostly attributed to teachers' lack of alignment of planning, implementation, and evaluation of learning outcomes. Similarly, Arabic Language Department (2009) and Ministry of Education (2007) reported there are difficulties for learning and teaching Arabic in schools, and the majority of these schools report complaints about their students' proficiency.

In fact, "classroom evaluation has powerful direct and indirect impacts, which may be positive or negative, and thus deserves very thoughtful planning and implementation" (Crooks, 1988, p. 438). Rea-Dickins (1994) found evaluation activities appear to have very significant effects on students' learning language. Thus, ReaDickins (1994) provided a definition for the evaluation in teaching languages which is the process of collecting, analyzing and interpreting information about teaching and learning in order to make informed decisions that enhance student achievement and the success of educational programs.

There is a gap in the literature regarding the skills and strategies that Arabic language teachers need to be trained to better evaluate their students' learning. This paper focuses on evaluation process of teaching Arabic language lessons, what evaluation skills teachers need how they are related to planning and implementation.

\subsection{The Statement of Purpose}

The purpose of this current study was to investigate factors that influence the evaluation skill needs of Arabic language teachers at all public and private schools in the Majmaah School District, Saudi Arabia. In order to fulfill this purpose, research questions focused on the Arabic language teachers' evaluation skills used during teaching Arabic language lessons.

\subsection{Research Questions}

This multiple regression study sought to answer three research questions, which are as follows:

Q1) How do Arabic language teachers in the Majmaah School District rank their needs of multiple components of evaluation skills?

Q2) To what extent do the self-reported planning skill needs of Arabic language teachers in the Majmaah School District predict their self-reported evaluation skills?

Q3) To what extent do the self-reported implementation skill needs of Arabic language teachers in the Majmaah School District predict their self-reported evaluation skills?

\subsection{Conceptual Framework}

This section focuses on theories and concepts that are relevant to this research topic. Desimone (2009) offered ideas to improve the quality of professional development in general. This researcher examined recent research findings that reflect which training programs can increase teachers' knowledge, improve their teaching practices, and help students to improve academically. Researchers like Desimone (2009), Wei, Darling-Hammond, and Adamson (2010), and Kedzior and Fifield (2004) identified seven characteristics associated with successful programs. The first characteristic is content that focuses on increasing the teachers' subject matter knowledge to help students to learn. The second characteristic is active learning, which means the programs should be more engaging for participating teachers. The third characteristic of teachers' training programs should derive from a mixture of different methods of training such as observation of expert teachers, feedback after the observations, reviewing students' work, and discussions.

The next characteristic is coherence, which means the core being taught in these programs should match teachers' knowledge and beliefs and match the policies and regulations of the schools, the school districts, and the department of education. Collective participation is also another characteristic, which means teachers learn more effectively when they participate in the learning with teachers from the same subject, schools, grades, and school districts (Desimone, 2009; Kedzior \& Fifield, 2004; Wei et al., 2010). The next characteristic is that increasing teachers' knowledge and skills should be continual and contain inquires, discussions, reflections, and include practices. Finally, the teachers' needs, and interests should be addressed in order to support the individuals' and 
the educational organizations' improvement.

Desimone (2009) advocated that teachers should increase knowledge and practices or change their attitude or beliefs, and then they should use their new knowledge, practices, attitudes, and beliefs to improve their instruction and pedagogy in their own classrooms. The theory of action is presented in Figure 1.
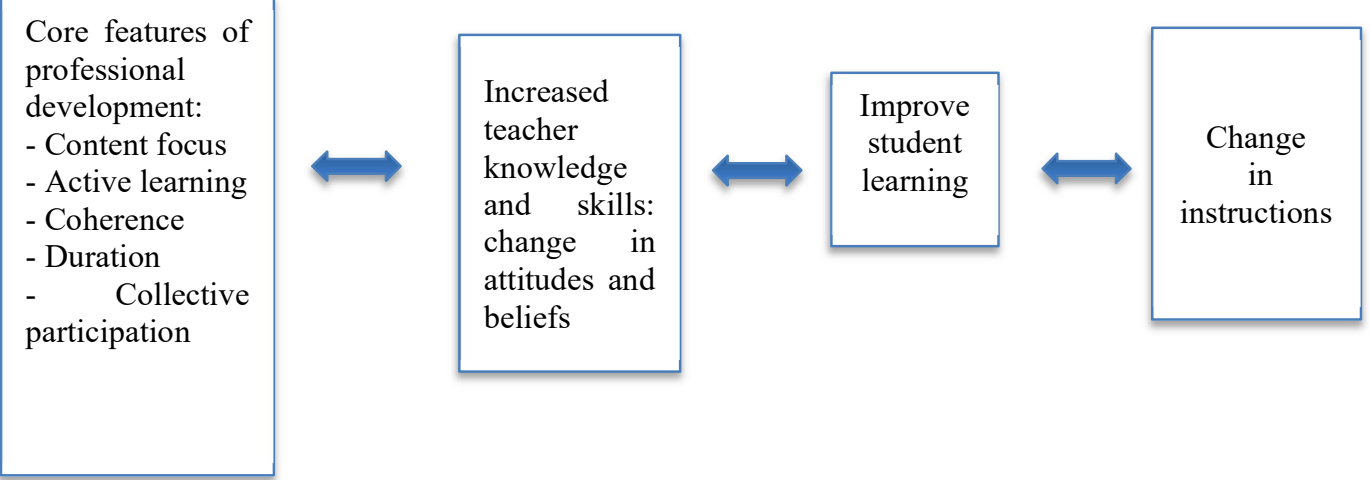

Figure 2. A Theory of Action for Teachers' Professional Development Programs

(Figure created by author from the research of Desimone, 2009)

\section{Previous Studies about Teaching Arabic Language}

The Arabic language is one of the major languages in the world beside Latin, English, French, Spanish, and Russian. Hall Haley and Ferro (2011) stated that Arabic is one of the 13 languages designated as critical to global citizenship by the U.S Department of State. Also, it is the language of Arab countries that occupy a large area of the world; over 200 million people around the world speak this language, and it is the language of the Islamic religion, which is spread throughout in the world (Chejne, 1999; Dahbi 2004; Department of Arabic and Islamic Studies 2012).

Furthermore, each of the major languages has its own characteristics that differentiate it from other languages. For example, the Arabic language has 28 letters and eight vowels. It is written and read from right to left. The adjective in Arabic always comes after the noun for example "place nice" instead of "nice place". Also, Arabic does not use the verb "to be" in the present tense and the auxiliary verb (be, do, have) does not apply in Arabic. Finally, the indefinite article does not exist in Arabic (Albab, 2009; Chejne, 1999; Shoebottom, 2011).

The Arabic language is similar to other languages in term of dialects. There is an old or classical Arabic, which is the origin of the Arabic language. The Holy Quran, a compilation of the verbal revelations given to the Holy Prophet Muhammad, represents this dialect. Also, there is a modern standard Arabic, which emerged from the classical Arabic. This dialect can be seen in books, media, or formal conversation among Arabic people from different countries. The final type is the local dialect, which also come from the original language and is influenced by other languages (Albab, 2009: Alkhalifa, 2004).

Therefore, teaching Arabic has challenges and has been paid a significant amount of attention (Aladgam, 2003: Shehata, 2000). The MOE (Ministry of Education - Saudia Arabia) educates Arabic language teachers during their in-service to achieve the aim of teaching Arabic in schools. MOE aims to teach Arabic for students for the following purposes: (a) to provide students with sets of words, structures, and method of linguistics eloquences that will help them to understand the classical language dialect including the holy Quran and Islamic and Arabic heritage; and (b) to improve students' language abilities of understanding, analyzing, and evaluating language events that face them, in order to produce language structures that are characterized by accuracy, fluency, and quality (MOE, 2012).

Al Qatawneh (2000) stated that Arabic language teachers must be skilled and qualified for teaching Arabic because it is a good way to spread the history, culture, and language of Arab nations. However, Al Qatawneh (2000), Al Manea and Olaimat (2014), and, Khudair (1998) found that Arabic language teachers have fewer teaching skills, including evaluation, and are not able to teach students effectively and with enjoyment. This weakness shows in the outcomes of their students in the areas of reading and writing proficiency. In addition, Al Manea and Olaimat (2014) found that Arabic language teachers often have less interest in personal professional development and are not interested and motivated in teaching.

Regarding the wellnesses and motivation for improving teaching, Al- Basheer, et al. (2015) stated that there was no significant difference among experienced and non-experienced teachers in their teaching skills. In other words, they have the same teaching skills. However, when teachers increased their teaching experiences, participation in professional development learning decreased (Olaimat, 2013; Yaser, Baker, Robinson-Kurpius, Krause, \& Roberts, 2006). They proposed that the reason for less interest in participation by experienced teachers was because they had already participated more than less experienced teachers during their service. Therefore, 
highly experienced teachers may have had higher professional competencies than others (Olaimat, 2013).

Furthermore, Al- Basheer, Ashraah, and Alsmadi (2015) and Al Ghamdi (2015) realized that Arabic language teachers (ALT) needed to improve assessments (i.e., evaluation) skills. Most Arabic language teachers use written examinations to evaluate their students. Khudair (1998) listed some reasons for this weakness in teaching Arabic: the characteristics of the Arabic language itself; the characteristics of Arabic teachers and their teaching methods; the characteristics of Arabic learners; some factors related to the schools' leaderships; and the educational system.

Hence, in order to achieve the aim of teaching Arabic in schools, Arabic language teachers, should be asked to identify their needs and their difficulties in the teaching process. For example, Hall Haley and Ferro (2011) found that Arabic language teachers in the US needed two major aspects to be educated. These were classroom management and understanding the cultural differences.

Much research has been done on Arabic language teachers' background and professional development other than teaching skills for Arabic language lessons (Al Manea and Olaimat, 2014; Al- Basheer, Ashraah, and Alsmadi, 2015; Khudair, 1998). The importance of this study is that the professional development literature is missing research concerning the influence of planning and implementation skills on evaluation skills for Arabic language teachers.

\section{Methodology}

The quantitative research design allows investigator to "examine a situation as it is" (Leedy \& Ormrod, 2016, p. 182). The present quantitative study includes both a descriptive research design and inferential statistic research design. Gall et al. (1996) wrote that "descriptive research is a type of quantitative research that involves making careful descriptions of educational phenomena" (p. 374). Descriptive research includes collection and analysis of quantitative data that describes sample perceptions, characteristics, and personal needs about the status of a situation. Inferential statistics are concerned with drawing conclusions about populations by testing hypotheses on samples and generalizing to the population (Coolidge, 2021).

\subsection{Research Setting}

This study took place at Majmaah School District, Majmaah City, Saudi Arabia. This city is located in the central province of the country. There are 28800 students, 3911 teachers, and 344 schools in the Majmaah School District. There are three sub-districts that are called the Office of Education in Majmaah School district. The main office is located on the main campus. The other three offices are located in counties that are tied to the main city, Majmaah. These counties are Howat-Sadyer, Teemer, and Alrtawiah. Each office supervises schools that are in its district and there are 237 supervisors in the Majmaah School District (see Table 1).

Table 1: Overview of Majmaah School District

\begin{tabular}{|l|l|l|l|l|l|l|l|l|}
\hline \multirow{2}{*}{ Population } & \multicolumn{9}{|l|}{ Male } & Female & Total \\
\cline { 2 - 9 } & $\begin{array}{l}\text { ELM } \\
\text { school }\end{array}$ & $\begin{array}{l}\text { MID } \\
\text { school }\end{array}$ & $\begin{array}{l}\text { HIGH } \\
\text { School }\end{array}$ & $\begin{array}{l}\text { ELM } \\
\text { School }\end{array}$ & $\begin{array}{l}\text { MID } \\
\text { School }\end{array}$ & $\begin{array}{l}\text { HIGH } \\
\text { School }\end{array}$ & $\begin{array}{l}\text { Pre- } \\
\text { School }\end{array}$ & \\
\hline students & 7,260 & 3,205 & 3,096 & 7,418 & 3,312 & 2,538 & 1,971 & 28,800 \\
\hline teachers & 815 & 449 & 389 & 994 & 572 & 597 & 95 & 3911 \\
\hline schools & 72 & 40 & 28 & 82 & 53 & 35 & 34 & 344 \\
\hline
\end{tabular}

\subsection{Population and Sample}

The population of this study was all Arabic language teachers in the public and private schools in the Majmaah School District, Saudi Arabia. The variety in size of the schools was one reason for using the Majmaah School District. Some schools within the district had a large number of faculty, staff, and students; some schools have a limited number of students and teachers. A second reason for selecting the school district was based on the district's variety of school types. There are both suburban and urban schools. Finally, the first author works for that school district which provided easier access in order to collect the data and make further investigations.

To finalize the population from which a volunteer sample was recruited, the researchers used the following selection criteria. Arabic language teachers who were administrators, subject supervisors, students' advisors, or classroom teachers who teach all subjects to K-3 grade students were not included. In addition, primary grade teachers were not considered because they had different subject supervisors and may have participated in different areas of professional development programs or activities than those who teach language arts and their instructional assignment. Also, there were some teachers whose major had been Arabic, but they taught different subjects because of the lack of other subjects' teachers. For example, Arabic language teachers can teach Islamic studies, or social sciences (Fhad. Alolah, Teachers' Affairs, personal communication, December 20, 2017). In summary, participants: (a) currently were Arabic language teachers at any level of school (elementary, middle, or high school teachers); (b) taught Arabic language at the time of this study; and (c) were certified for teaching Arabic language. Using these criteria, between 250-280 Arabic language teachers in 310 schools were considered as potential participants in this study. 


\subsection{Instrumentation}

In the descriptive quantitative research method, the data were collected through the use of a survey. The survey for this study was an extension of the first author's previous work (Alzahrani, 2019) in the area of professional development for Arabic language teachers in Saudi Arabia educational system. This three-part survey identified teachers' Planning Needs (13 questions), Implementation Needs (13 questions), and Evaluation Needs (8 questions) during the process of teaching Arabic language. Participants rated each item using a three-point scale $(1=$ not needed; 2 = less needed; $3=$ most needed). In addition, the survey collected data for teacher gender (male, female), level of education (Bachelor, Master's, Doctoral), and years of teaching experience (1- 5 years, 6 to 12 years, more than 12 years).

The researcher followed standardized procedures to ensure the validity and reliability of the instrument. An expert panel in field of education validated the survey to ensure it measured what it is supposed to measure (Creswell, 2003). The researcher used a computational program to measure the internal reliability (Chronbach's Alpha) of the survey (Pallant, 2016). According to Alzahrani (2019), the Planning Needs $(\alpha=.83)$, Implementation Needs $(\alpha=.85)$, and Evaluation Needs $(\alpha=.89)$ scales had good internal consistency. For the current study, the Cronbach alpha coefficient for each scale was above .8 which is the preferred Cronbach alpha coefficient (DeVellis, 2012: Pallant, 2016).

\subsection{Data Collection}

Permission was obtained from the Majmaah School District in Saudi Arabia and the researchers' related university Institutional Review Board to distribute the electronic survey to all Arabic teachers in the district schools. After receiving required approvals, the first author sent the electronic survey to the Chair of the Arabic language department in each office at the district. That supervisor forwarded the survey to all Arabic language teachers in the population. An electronic survey is easier for the participants to complete at their convenience and in their available time. To increase the response rate, three weeks after sending the survey, the first author contacted the supervisors to remind the participants to complete the survey and to thank those who already had done so.

\subsection{Data Analysis}

Data were analyzed to answer each research question. For Research Question 1, descriptive statistics included frequency and percent, mean, and standard deviation. For Research Questions 2 and 3, the inferential statistics technique, standard multiple regression was used. Multiple regression can reveal how well a set of variables can predict a particular outcome (Pallant, 2016). The regression model included the two continuous independent variables: planning skill needs and implementation skill needs, and one categorical independent variable: years of teaching experience and the continuous dependent variable: evaluation skill needs. This technique identified the amount of unique variance in the dependent variable (evaluation skill needs) which could be explained by planning and implementation skill needs and years of teaching experience.

\subsection{Results}

From the estimated population of 250-280 Arabic teachers, 158 individuals responded to the survey (response rate $=56.4 \%$ to $63.2 \%$ ). Table 2 shows the descriptive characteristics of the participants. Moreover, descriptive statistics were calculated for the Planning Needs Scale $(\mathrm{m}=20.29 ; \mathrm{sd}=3.79)$ and Implementation Needs Scale $(\mathrm{m}=37.11 ; \mathrm{sd}=4.70)$

Table 2. Descriptive Analysis of Respondents

\begin{tabular}{|c|c|c|c|}
\hline & & $\mathrm{n}$ & $\%$ \\
\hline \multirow[t]{2}{*}{ Gender } & Male & 124 & 78.5 \\
\hline & Female & 34 & 21.5 \\
\hline \multirow[t]{3}{*}{ Level of education } & Bachelor & 141 & 89.2 \\
\hline & Master's & 15 & 9.5 \\
\hline & Doctoral & 2 & 1.3 \\
\hline \multirow[t]{3}{*}{ Years of teaching } & 1 to 5 years & 24 & 15.2 \\
\hline & 6 to 12 years & 50 & 31.6 \\
\hline & More than 12 years & 84 & 53.2 \\
\hline
\end{tabular}

To answer Research Question 1, descriptive statistics for the dependent variable as measured by the Evaluation Needs Scale were calculated. The statistics included frequency and percent for each response to the eight items. In addition, the mean and standard deviation were calculated for each of the eight elements and the total scale (Table 3). Results presented in descending order of the mean for each element revealed all elements in the Evaluation Needs Scale were ranked between less needed and most needed (mean range $=2.44$ to 2.61). Most items were reported as closer to most needed. 
To answer Research Questions 2 and 3, multiple regression was used to assess the ability of three independent variables: teaching experience, planning skill needs, and implementation skill needs to predict the professional development evaluation skill needs of Arabic teachers. Preliminary analyses to test the assumptions of normality, linearity, multicollinearity, and homoscedasticity revealed no significant violations. The initial regression model with three predictors explained $46.80 \%$ of the variance in evaluation needs, $F(3,157)=46.96, p<.00$. Planning skill needs and implementation skill needs were the only statistically significant predictors.

The final regression model removed teaching experience as a predictor of the professional development evaluation needs of Arabic teachers. Analysis revealed both remaining predictors explained $47.10 \%$ of the variance (unique and shared) in evaluation needs, $F(2,157)=70.80, p=.00$. Planning skill needs recorded a higher beta value (beta $=.43, p<.00$ ) than implementation skill needs (beta $=.32, p .<.00$ ). That is, of these two predictors planning skill needs made the larger unique contribution.

Table 3. Ranking of Evaluation Skill Needs (RQ 1)

\begin{tabular}{|c|c|c|c|c|c|c|c|c|}
\hline \multirow[t]{2}{*}{ Evaluation Skill } & \multicolumn{2}{|c|}{1} & \multicolumn{2}{|c|}{2} & \multicolumn{2}{|c|}{3} & \multirow[t]{2}{*}{$\mathrm{M}$} & \multirow[t]{2}{*}{ SD } \\
\hline & $\mathrm{n}$ & $\%$ & $\mathrm{n}$ & $\%$ & $\mathrm{n}$ & $\%$ & & \\
\hline $\begin{array}{l}\text { - Employing the results of evaluations to amend the } \\
\text { process of planning and implementing procedures for } \\
\text { teaching Arabic }\end{array}$ & 10 & 6.3 & 41 & 25.9 & 107 & 67.7 & 2.61 & .60 \\
\hline $\begin{array}{l}\text { - Constructing language evaluation processes in } \\
\text { accordance with proper criteria }\end{array}$ & 7 & 4.4 & 49 & 31.0 & 102 & 64.6 & 2.60 & .57 \\
\hline $\begin{array}{l}\text { - Ability to apply different types of language } \\
\text { evaluation techniques }\end{array}$ & 6 & 3.8 & 53 & 33.5 & 99 & 62.7 & 2.58 & .56 \\
\hline $\begin{array}{l}\text { - Executing language evaluation processes in } \\
\text { accordance with correct procedures }\end{array}$ & 8 & 5.1 & 54 & 34.2 & 96 & 60.8 & 2.55 & .59 \\
\hline $\begin{array}{l}\text { - Ability to recognize the characteristics of good } \\
\text { language assessment }\end{array}$ & 10 & 6.3 & 53 & 33.5 & 95 & 60.1 & 2.53 & .61 \\
\hline $\begin{array}{l}\text { - Using continuous assessment methods to measure } \\
\text { students' linguistic progress }\end{array}$ & 14 & 8.9 & 54 & 34.2 & 90 & 57 & 2.48 & .65 \\
\hline $\begin{array}{l}\text { - Analyzing and interpreting the findings of language } \\
\text { evaluation }\end{array}$ & 14 & 8.9 & 56 & 35.4 & 88 & 55.7 & 2.46 & .65 \\
\hline $\begin{array}{l}\text { - Engaging students in a self-evaluation of their } \\
\text { linguistic activities }\end{array}$ & 18 & 11.4 & 52 & 32.9 & 88 & 55.7 & 2.44 & .69 \\
\hline Total Evaluation Scale & & & & & & & 20.29 & 3.79 \\
\hline
\end{tabular}

$1=$ not needed; $2=$ less needed; $3=$ most needed

\section{Conclusions and Discussion}

Generally, the findings of this study are consistent with Desimone (2009) Al Qatawneh (2000), and Al-Hazmi (2003) who reported that professional development in teachers facilitate a change in teaching skills that can lead to improved student achievement. They suggested that teachers should increase knowledge and practices or change their attitude or beliefs and then they should use their new knowledge, practices, attitudes, and beliefs to improve their instruction and pedagogy in their own classrooms. Findings from Research Question reflect teachers' selfreported need for evaluation skills.

Another major finding of this study was that planning and implementation skill needs of Arabic teachers are significantly related to their evaluation skill needs. That is, Arabic teachers who need planning and implementation professional development also need evaluation professional development. This is consistent Disha (N.A) who reported that classroom teachers pay attention to three components when they evaluate their students. First is the purpose of instruction indicated by the learning objectives - the "WHY". Second is the plan that describes the learner experiences to attain the learning objectives - the "HOW". These two components are considered the planning process of teaching. Third is the practices which actually take place in the classroom- the "WHAT" which is the implementation skills. All three components need to be connected in order for the evolution process occurs in the taught subject.

Additionally, Arabic Language Department (2009), Ministry of Education (2007), and Al Ghamdi (2015) addressed different issues regarding teaching and learning Arabic language at public schools in Saudi Arabia. However, when planning, implementation, and evolution are connected to each other, they may improve teachers' alignment of learning outcomes with learning activities and assessment activities.

The literature review indicated that there are differences in willingness of Arabic teachers to attend professional development programs or activities. The findings of this study indicated Arabic teachers skilled in planning and implementation were also skilled in evaluation processes. Thus, this finding was not influenced by years of teaching experience of Arabic teachers. 
To conclude, professional development programs for Language Art teachers that include Arabic language teachers should be supported through the outcome-based learning. It starts with what students are expected to learn (planning). Then, focusing on the creation of teaching and learning environments that will assist students in reaching the desired learning (implementation). Finally, involving the use of assessment that can provide feedback about the level of learning that has been achieved (evaluation). Teachers' planning and implementation needs predict their evaluation skill needs, regardless of their years of teaching experience.

\section{References}

Aladgam, R. A. (2003). Developing a preparation programme for teachers of Arabic language in the light of requirements and changes of the era. Retrieved from http://uqu.edu.sa/page/ar/4988

Al-Basheer, A., Ashraah, M., \& Alsmadi, R. (2015). Arabic Language teachers and Islamic Education teachers' awareness of authentic assessment in Jordan. Teacher Development, 19(4), 483-495. doi:10.1080/13664530.2015.1064824

Al-Hazmi, S. (2003). EFL teacher preparation programs in Saudi Arabia: Trends and challenges. Tesol Quarterly, $37(2), 341-344$

Al Qatawneh, S. (2000) Teaching competencies necessary to improve the classroom teaching of the Arabic language in the primary stage in the schools of Karak State from the point of view of teachers and the degree of their practice (Unpublished masters' thesis). University of Mu'tah, Karak, Jordan.

Al Manea, M., \& Olaimat, H. (2014). The extent to which Arabic language teachers practice modern professional skills in order to meet the requirements of educational development in the country of Kuwait. Journal of Education, 28 (112) 15-31. (Arabic resource).

Alnahdi, G. H. (2014). Educational change in Saudi Arabia. Journal of International Education Research, 10(1), $1-6$.

Al Ghamdi, A. H. A. (2015). Designing a continuing professional development programme for enhancing the teaching skills of teachers of the Arabic language(Order No. 10086913). Available from ProQuest Dissertations \& Theses Global. (1779543464).

Arabic Language Department. (2009). Final report: The first meeting of the heads of the Arabic language departments in the Administrations of Education in the Kingdom of Saudi Arabia. Onaizah: General Directorate of Educational Supervision in Onaizah.

Al-bab (2009). The Arabic language: Introduction. An open door to the Arab world. Retrieved from http://www.albab.com/arab/language/lang.htm\#Introduction

Alkhalifa, H. J. (2004). Chapters in teaching Arabic (4th ed.). Riyadh: Alrushd Library.

Alzahrani, F. S. (2019). Professional development needs of Arabic language teachers from their perspective: In the Majmaah School District, Saudi Arabia (Order No. 13880007). Available from Dissertations \& Theses @ Saint Louis University. (2237717190). Retrieved from https://ezp.slu.edu/login?url=https://searchproquest com.ezp.slu.edu/docview/2237717190?accountid $=8065$

Beach, R. W. (2011). Issues in analyzing alignment of language arts common core standards with state standards. Educational Researcher, 40(4), 179-182.

Borko, H. (2004). Professional development and teacher learning: Mapping the terrain. Educational Researcher, 33(8), 3-15.

Chejne, A. G. (1999). The Arabic language: Its role in history. Minneapolis, MN: University of Minnesota Press.

Coolidge, F.L. (2021). Statistics: A gentle approach (4th ed.). Los Angeles; Sage.

Dahbi, M. (2004). English and Arabic after 9/11. The Modern Language Journal, 88(4), 628-631.

DeVellis, R. F. (2012). Validity. Scale development: Theory and applications, 3.

Desimone, L. M. (2009). Improving impact studies of teachers' professional development: Toward better conceptualizations and measures. Educational Researcher, 38(3), 181-199.

Disha. $\mathrm{M}$ (N.A) Evaluation in Teaching and Learning Process. Retrieved from http://www.yourarticlelibrary.com/statistics-2/evaluation-in-teaching-and-learning-process-education/92476

Hall Haley, M., \& Ferro, M. S. (2011). Understanding the perceptions of Arabic and Chinese teachers toward transitioning into US schools. Foreign Language Annals, 44(2), 289-307.

Jabbarifar, T. (2009). The importance of classroom assessment and evaluation in educational system. In Proceedings of the 2nd International Conference of Teaching and Learning (pp. 1-9).

Kedzior, M., \& Fifield, S. (2004). Teacher professional development. Education Policy Brief, 15(21), 76-97.

Khudair, R, (1998). The causes of the phenomenon of linguistic weakness in the students of the basic stage from the point of view of teachers of Arabic language in the province of Irbid. (Unpublished masters' thesis). Yarmouk University. Erbd, Jordan.

Ministry of Education. (2007). Arabic language curriculum for elementary and intermediate stages in public education. Riyadh, SA: Author.

Ministry of Education. (2012). Summary statistics on general education in the KSA academic year 2010/2011. 
Retrieved

from https://www.moe.gov.sa/Arabic/PublicAgenciesAndDepartments/EducationalInformationCenter/Page s/th-m.aspx

Newell, G. E., Beach, R., Smith, J., \& VanDerHeide, J. (2011). Teaching and learning argumentative reading and writing: A review of research. Reading Research Quarterly, 46(3), 273-304.

Olaimat, H. (2013). The degree of parental practice of reading, writing and emotional readiness skills among preschool children. $A A B U$-Dspace, 116 (1). Retrieved from http://repository.aabu.edu.jo/jspui/

Rea-Dickins. P. (1994) Evaluation and English Language Teaching. Language Teaching 27, 71-91.

Shoebottom, P. (2011). The differences between English and Arabic. Retrieved from http://esl.fis.edu/grammar/langdiff/arabic.htm

Shehata, H. (2000). Teaching Arabic language between theory and practice (4th ed.). Cairo, EG: Aldar Almasriah Allabananeah.

Wei, R. C., Darling-Hammond, L., \& Adamson, F. (2010). Professional development in the United States: Trends and challenges (Vol. 28). Dallas, TX: National Staff Development Council.

Yaser, S ., Baker, D., Robinson-Kurpius, S., Krause, S., \& Roberts, C. (2006). Development of a survey to assess K-12 teachers' perceptions of engineers and familiarity with teaching design, engineering, and technology. Journal of Engineering Education, 95(3), 205-216. 